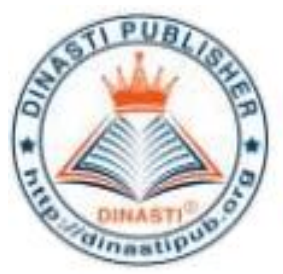

\title{
THE EFFECT OF GREEN RECRUITMENT, GREEN TRAINING ON EMPLOYEE PERFORMANCE IN PT TRU USING ORGANIZATION CITIZENSHIP FOR ENVIRONMENT AS MEDIATION VARIABLE
}

\author{
Siska Agustina Sinaga ${ }^{1}$, Lenny C. Nawangsari ${ }^{2}$ \\ ${ }^{1)}$ Postgraduate Masters in Management, Mercubuana University,Jakarta, Indonesia \\ ${ }^{2)}$ Postgraduate Masters in Management, Mercubuana University,Jakarta, Indonesia
}

\begin{tabular}{|l|l|}
\hline $\begin{array}{l}\text { ARTICLE INFORMATION } \\
\text { Received: 11/12/2019 } \\
\text { Revised: 13/12/2019 } \\
\text { Issued: 16/12/2019 }\end{array}$ & $\begin{array}{l}\text { Abstract: This study aims to analyze the effect of } \\
\text { green recruitment, green training, and OCBE on } \\
\text { employee performance. This type of research is } \\
\text { carried out quantitatively and for the research method } \\
\text { used is the associative explanatory level method. The } \\
\text { object of this research is PT TRU. The sampling } \\
\text { method used was a probability sampling with a } \\
\text { sampling technique using simple random sampling } \\
\text { E-mail: } \\
\text { sinagasiska@gmail.com } \\
\text { lenny.christina@mercubuana.ac.id } \\
\text { performed using Structural Equation Modeling (SEM) } \\
\text { with soft ware Partial Least Square (smart - PLS). The } \\
\text { results obtained in this study: 1) Green recruitment, } \\
\text { green training, and Organization Citizenship for } \\
\text { Behavior (OCBE) have positive and significant effect } \\
\text { on employee performance, 2) Green recruitment and } \\
\text { green training have a positive and significant effect on } \\
\text { employee performance through Organization } \\
\text { Citizenship for Behavior (OCBE). } \\
\text { Keywords: Green Recruitment, Green Training, } \\
\text { Organization Citizenship for Behavior (OCBE), } \\
\text { Employee Performance. }\end{array}$ \\
\hline
\end{tabular}

\section{INTRODUCTION}

Business competition in globalization era made many companies compete to maintain their market share. This condition requires organization respond to adapting these changes for 
to be able to compete in global competition. The company expected not only focus on increasing profits, but how the company's ability to manage the organization's environment.

Performance is person success level during a certain period in carry out tasks with good responsibilities. Employee performance is an important thing in an organization, because it can affect organizational performance. Company performance service shown by total of customers use the company's services and customer loyalty level in reusing these services.

For good management, companies must having knowledge, highly skilled employees and efforts to manage the company as optimal as possible so that employee performance increases. Good employee performance show on high work results while low employee performance will result in low performance.

According to Moeheriono (2012: 95), performance is achievement level on program implementation of activities or policies in realizing the goals, objectives, vision and organization mission as outlined through the strategic planning of an organization.

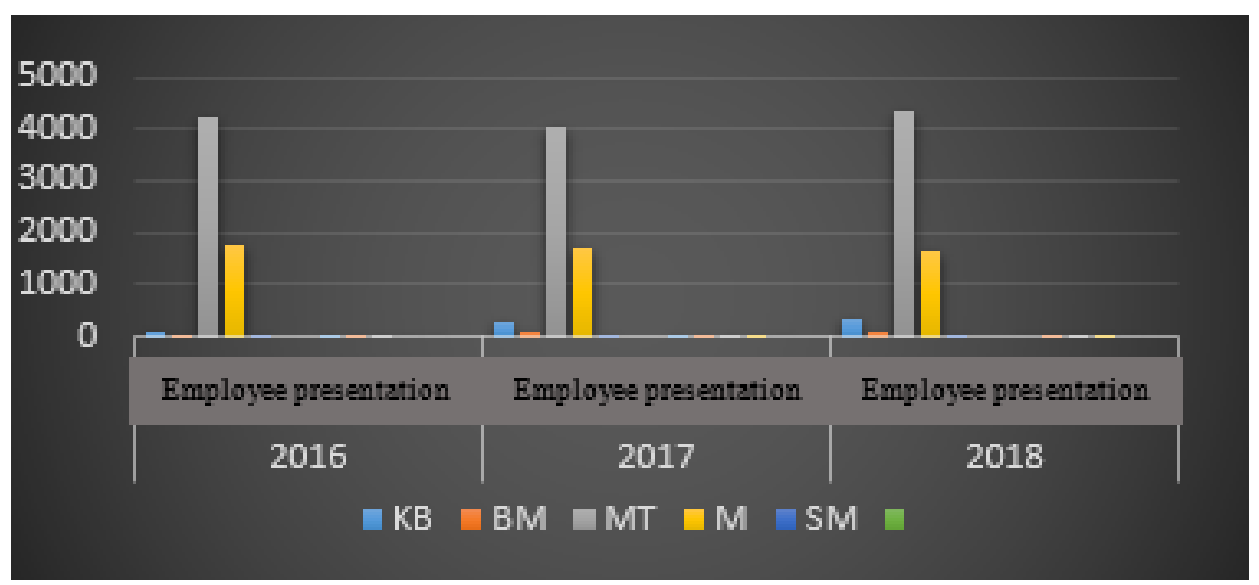

\section{Figure 1. 2016-2018 Employee Performance Assessment Source: PT TRU's Company Data}

Figure 1 shows that in the period 2016 to 2018 there were still employees who received ratings under the category which means there were employees who were still lacking in achieving targets. In addition, there are still employees contributes minimally assessment, it means there are employees get lacking in achieving. There was a decrease number in employees who received satisfactory category. However, overall the results of employee performance appraisals have a tendency towards improvement, this can be seen from the increase in employees who get an assessment with the category of meeting targets.

The percentage of employees every year has fluctuating changes, especially for employees who get satisfactory performance scores. A company declared good if work appraisal of its employees continues to experience a significant increase. Therefore, the rectutment process is needed at PT.TRU to get quality employees and a training for their employees so that they can continue to provide satisfactory performance values as shown in the percentage that continues to rise in the years to come. 


\section{LITERATURE REVIEW \\ Green Recruitment}

Green Recruitment is producing candidates process in accordance with existing positions in the company through an online process and recruited they can maintain environmental values. According to Jabbour (2011) in Aranganathan (2018) green recruitment is to produce candidates who are committed to the environment and willing to contribute to the company. Meanwhile according to Ahmad in Adimuthu (2017) green recruitment is a process to get potential candidates and make the importance of the environment as a criterion in the recruitment process.

According to Mudji Astuti (2018) factors that influence Green Recruitment : 1) including environmental criteria, 2) company commitment to the environment during the recruitment process, 3) In job advertisements include elements that contain knowledge about the environment, 4) Looking for prospective candidates who has competence in environmental management.

\section{Green Training}

Green Training is the training process that keep green the environment it can be done online for increase employee knowledge of the importance of protecting the environment. Kjaerheim (2005) in Bilal (2018) said that green training can increase employee knowledge about the environment and make employees more sensitive about environmental issues. Meanwhile, according to Lenny and Ahmad (2018) green training is a process that trains employees to have knowledge about work methods that save energy and provide opportunities for employees to be involved in solving environmental problems. Renwick in Miraj (2018) the factors that influence green training are as follows: 1) Informing about environmental management training, 2) Analyzing the training needs to find out the type of training that is environmentally friendly, 3) Providing training to employees about how work space is environmentally friendly, 4) Provide training to all employees on environmental management, safety, energy efficiency and recycling.

According to Jabbour (2015), indicators of green training are: 1) Conducting a number of training on the environment for all employees, 2) Every employee has the same opportunity to be trained on environmental issues, 3) Training on the environment is used effectively by all employees, 4) Conduct an evaluation of employee performance after environmental training.

\section{OCBE}

Kinicki and Fugate (2013: 164) said that Organization Citizenship Behavior is a voluntary action carried out by individuals even though the action is not part of their duties, but on the initiative to make a positive contribution to the organization. Organization Citizenship Behavior for Environment (OCBE) according to Paillé et al., 2013 in Sakher (2017) is voluntary behavior by people in an organization that aims to improve the environment. Meanwhile, according to Boiral (2009) in Nhat (2018) Organization Citizenship Behavior for Environment (OCBE) is a development of Organization Citizenship 
Behavior (OCB), which is behavior that voluntarily contributes to organizations to enhance environmental improvement.

According to Boiral \& Paillé (2015) Organization Citizenship Behavior for Environment (OCBE) has three dimensions: 1) Eco-initiatives, is voluntary behaviors to improve environmental performance, 2) Eco-civic engagement, is voluntary behavior of a person to involved in activities organized by companies that are pro-environment, 3) Ecohelping, is voluntary behavior of others to be environmentally conscious.

OCBE indicators consist of: 1) Eco-initiatives: a) always weigh the consequences of actions, b) initiatives in daily activities carry out actions regarding the environment, c) provide advice to others on how to protect the environment. 2) Eco-civic engagement: a) active in environmental activities in the organization, b) get information about environmental activities organized by the organization, c) contribute positively to the company's image. 3) Eco-helping: a) spontaneously helping others in considering the environment, b) encouraging others to be environmentally conscious, c) helping others express opinions about environmental issues.

\section{FRAMEWORK RESEARCH}

\section{1) Relationship of Green Recruitment with Organization Citizenship Behavior for} Environment (OCBE)

Jianfeng Jia et all (2018) said that when recruiting new employees, more attention should be paid to the environment quality awareness and employees environment. Recruited employees through the green recruitment process have better qualifications to understand the company's environmental management goals and solve problems based on environmental protection and motivate them to have environmentally friendly creativity.

$\mathrm{H}_{1}$ :Green recruitment has a positive and significant effect on organizational citizenship behavior for the environment (OCBE).

\section{2) Relationship between Green Training and Organization Citizenship Behavior for Environment (OCBE)}

According to Nhat Tan PHAM et al (2018) said that green training has a positive influence on OCBE which shows that green training can build green competency which encourages employees to work extra in environmental activities and to engage in green behavioral activities in the workplace voluntarily. when employees understand that the organization has a commitment to the environment they can instill an environmentally friendly organizational image in their self-concept, become committed to their environmental mission, and engage in environmentally friendly behavior in work activities. Green training plays an important role in improving OCBE.

$\mathrm{H}_{2:}$ Green training has a positive and significant effect on organizational citizenship behavior for the environment (OCBE).

\section{3) Relationship between Organization Citizenship Behavior for Environment (OCBE) and Employee Performance}


According to Sheena et al (2017) in a research journal said that the practice of green human resource management aims to make employees have environmentally friendly behavior. The implementation of GHRM practices through green lifestyle in the workplace will affect employee performance.

H3: Organization citizenship behavior for the environment (OCBE) has a positive and significant effect on employee performance.

\section{4) Relationship of Green Recruitment with Employee Performance}

Zirra et al (2017) in a research journal said that green recruitment has a significant effect on employee performance. The strengths and weaknesses of the company lies in its employees. A good recruitment strategy allows companies to get quality employees who can improve the performance of these employees.

$\mathrm{H}_{4::}$ Green recruitment has a positive and significant effect on employee performance.

\section{5) Relationship between Green Training and Employee Performance}

Previous research on green training effect on employee performance conducted by KKAH, Pallewaththa PWK (2018) entitled The effects of green training and development practices on employee performance explained that green training and development had a positive impact on employee performance. Employees must be given training and education in order to develop the skills and knowledge needed in the organization.

$\mathrm{H}_{5:}$ Green training has a positive and significant effect on employee performance.

\section{6) Relationship of Green Recruitment to Employee Performance through OCBE}

Previous research of employee green recruitment effect performance through OCBE conducted by Rini Setyo (2018) who said that green hrm (green recruitment) can increase the sense of ownership of employees in the organization to improve employee performance. $\mathrm{H}_{6}$ :Green recruitment has a positive and significant effect on employee performance through organization citizenship behavior for the environment (OCBE).

\section{7) Relationship of Green Training to Employee Performance through OCBE}

Previous research on the effect of green training on employee performance through OCBE conducted by Sakher (2017) that OCBE fully mediated the relationship between green training and performance.

$\mathrm{H}_{7}$ : Green training has a positive and significant effect on employee performance through organization citizenship behavior for the environment (OCBE). 


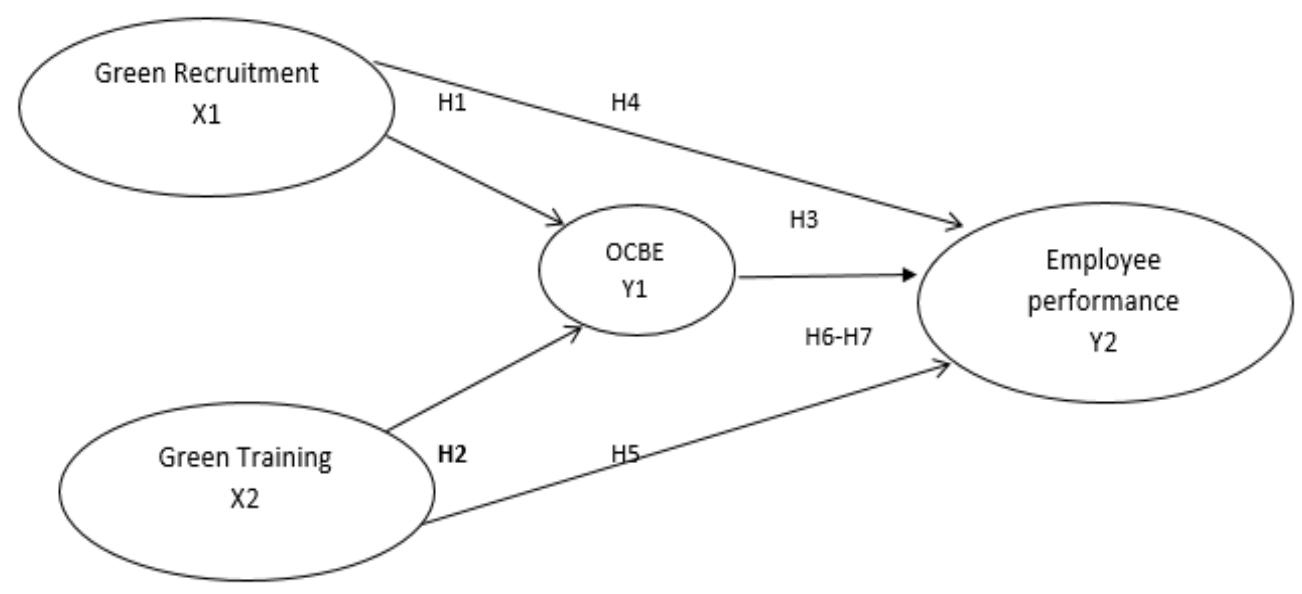

Figure 2. Research Thinking Framework

Source: Author's Processed Data (2019)

\section{RESEARCH METHODS \\ Research Design}

This research using quantitative methods by primary data in the surveys form. AThe research method is the associative explanatory level method used to determine the independent variable regression (X), with the dependent variable $(\mathrm{Y})$, is called regression research that aims to find the presence or absence of influence between variables, and if there is how much influence and means whether or not the influence.

\section{Data Collection Method}

The independent variables in this study are Green Recruitment and Green Training, the dependent variable is Employee Performance while the mediating variable is OCBE. The primary data in this study is the distributing result questionnaires to selected samples using a simple random sampling technique using a Likert scale. Secondary data in this study is in the form of employee performance evaluation report data for 2016-2018 issued by PT TRU personnel.

\section{Population and Sampling Method}

Population in this study were PT TRU employees . This research uses probability sampling technique withmethod simple random sampling. The sample collection technique used in this study is the Rao Purba formula, namely:

$$
\mathrm{n}=\frac{\mathrm{Z}^{2}}{4(\mathrm{MOE})^{2}}
$$

Then the samples in this study were 96,6 samples rounded up to 100 samples.

\section{Data Analysis Techniques}

This study uses components or variance Based Structual Equation to analyze data processing uses the Partial Least Square (smart - PLS) program. PLS is an alternative model of coverance-paradictive analysis in situations of high complexity and low theoretical support. There are two models in PLS Path modeling, they are Outer Model and Inner Model. 


\section{FINDINGS AND DISCUSSION}

Evaluation of Outer Model

\section{Convergent Validity}

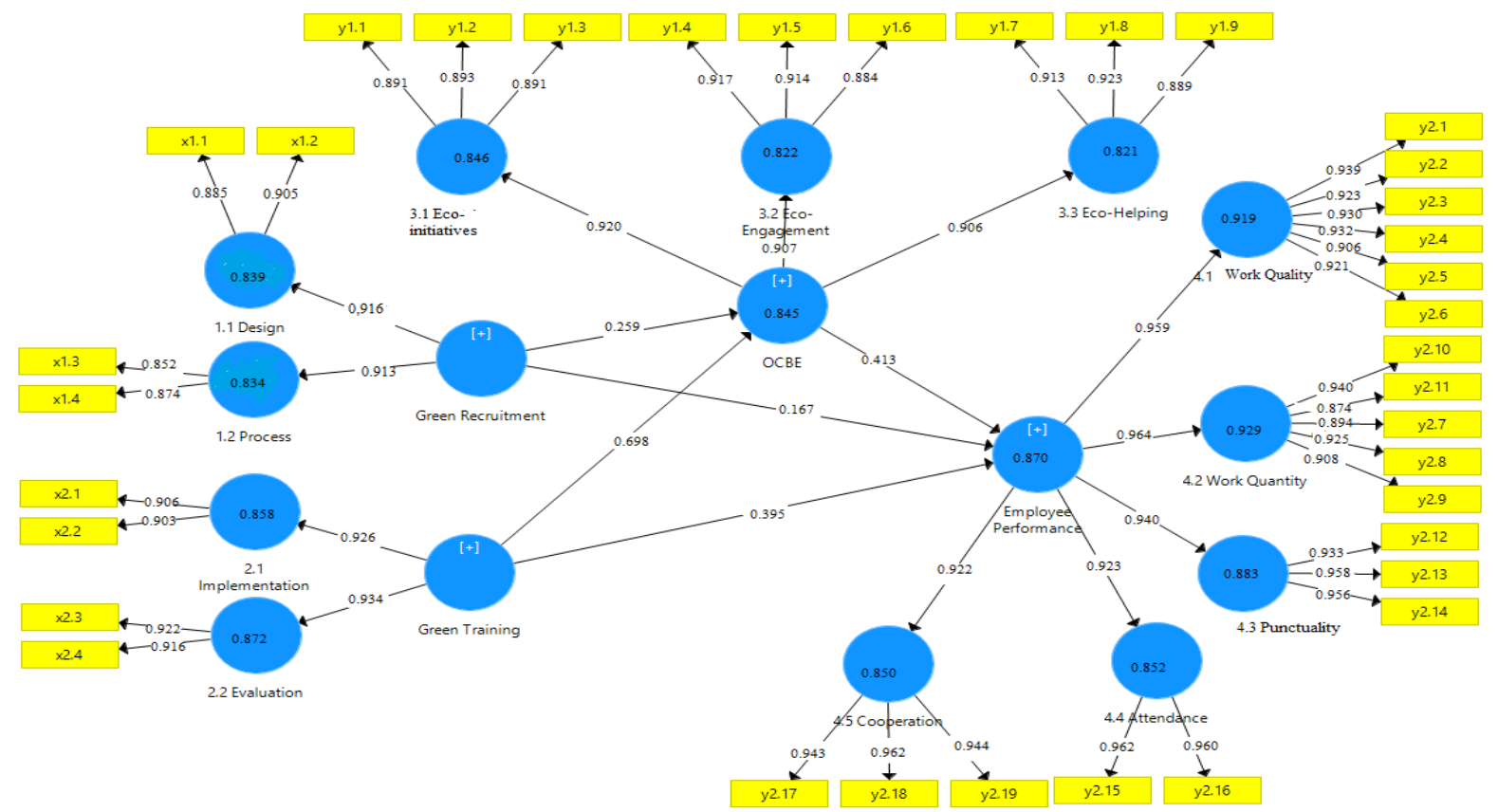

Figure 3. Convergent Validity

Using SmartPLS 3.2.8

Convergent Validity is a factor loading value on latent variables with the indicators. said to be valid if the loading factor> 0.7. Based on the measurement model above, all indicators have a loading factor greater than 0.7 so that it is declared significant.

\section{Average Variance Extracted (AVE)}

Value AVE used to measure the amount of variance that can be captured by the construct compared to the variance caused by measurement errors. Terms of AVE value> 0.50 . 


\begin{tabular}{|c|c|c|c|}
\hline Variable & Dimension & AVE Value & AVE Value \\
\hline \multirow[t]{2}{*}{ Green Recruitment $\left(\mathrm{X}_{1}\right)$} & 1.1 Design Work & 0.802 & 0.646 \\
\hline & 1.2 Recruitment Process & 0.744 & \\
\hline \multirow[t]{2}{*}{ Green Training $\left(\mathrm{X}_{2}\right)$} & 2.1 Implementation & 0.818 & 0.719 \\
\hline & 2.2 Evaluation & 0.844 & \\
\hline \multirow[t]{3}{*}{$\operatorname{OCBE}\left(Y_{1}\right)$} & 3.1 Eco-Initiatives & 0.795 & 0.674 \\
\hline & 3.2 Eco-Civic- Engagement & 0.820 & \\
\hline & 3.3 Eco-Helping & 0.825 & \\
\hline \multirow[t]{5}{*}{ Employee Performance $\left(\mathrm{Y}_{2}\right)$} & 4.1 Work Quality & 0.856 & 0.780 \\
\hline & 4.2 Work Quantity & 0.825 & \\
\hline & 4.3 Punctuality & 0.901 & \\
\hline & 4.4 Attendance & 0.924 & \\
\hline & 4.5 Cooperation Capability & 0.902 & \\
\hline
\end{tabular}

Based on the table above, all variables having value AVE $>0.50$ so each indicator has been able to reflect each of its variables validly.

\section{Cronbach's Alpha and Composite Reliability}

Having high reliability Data if the Cronbach's Alpha value> 0.6 and Composite Reliability value> 0.7 (Imam Ghozali, 2014).

Table 2. Cronbach's Alpha and Composite Reliability

\begin{tabular}{lccccc}
\hline \multicolumn{1}{c}{ Variable } & $\begin{array}{c}\text { Composite } \\
\text { Reliability }\end{array}$ & Requirements & $\begin{array}{c}\text { Cronbach's } \\
\text { Alpha }\end{array}$ & Requirements & Specification \\
\hline Green Recruitment $\left(\mathrm{X}_{1}\right)$ & 0.879 & $>0,7$ & 0.816 & $>0,6$ & Reliable \\
\hline Green Training $\left(\mathrm{X}_{2}\right)$ & 0.911 & $>0,7$ & 0.869 & $>0,6$ & Reliable \\
\hline OCBE $\left(\mathrm{Y}_{1}\right)$ & 0.949 & $>0,7$ & 0.939 & $>0,6$ & Reliable \\
\hline Employee Performance $\left(\mathrm{Y}_{2}\right)$ & 0.985 & $>0,7$ & 0.984 & $>0,6$ & Reliable \\
\hline
\end{tabular}

Source: Results of analysis using SmartPLS 3.2.8

\section{Evaluation of Inner Model}

Inner model is a test of the type and magnitude of influence of the independent latent variable on the dependent latent variable.

Table 3. The value of $R$ Square $\left(R^{2}\right)$ of Research Model

\begin{tabular}{|c|c|c|}
\hline Construct & $\boldsymbol{R}$ Square & $\begin{array}{c}\boldsymbol{R} \text { Square } \\
\text { Adjusted }\end{array}$ \\
\hline OCBE & 0846 & 0843 \\
\hline Employee Performance & 0872 & 0868 \\
\hline
\end{tabular}

Source: Result of analysis using SmartPLS 3.2.8 
Seen in the relationship table between constructs based on $R$-square Adjusted values can be explained that the OCBE variable is 0.843 , this shows that $84.3 \%$ of the OCBE variable can be influenced by thevariables Green Recruitment and Green Training, while the remaining $15.7 \%$ is influenced by other variables outside the study. Whereas the relationship between constructs is based on $R$-square Adjusted values can be explained that the Employee Performance variable is 0.868 , this shows that $86.8 \%$ Employee Performance variable can be influenced by thevariable Green Recruitment, Green Training, and OCBE variables, while the remaining $13.2 \%$ is influenced by other variables outside the study.

\section{Research Hypothesis Testing}

Table 4. Path Coefficient, $t$-Statistics, and P-Values Value

\begin{tabular}{|c|c|c|c|c|}
\hline Relationship between & $\begin{array}{c}\text { Original } \\
\text { Sample (O) }\end{array}$ & $\begin{array}{l}\text { T Statistics } \\
\text { (|O/STDEV|) }\end{array}$ & $\begin{array}{c}\mathrm{P} \\
\text { Values }\end{array}$ & Information \\
\hline \multicolumn{5}{|l|}{ Direct Effects } \\
\hline - Green Recruitment -> OCBE & 0.263 & 3.492 & 0.001 & $\begin{array}{l}\text { Significantly } \\
\text { Positive Influence }\end{array}$ \\
\hline - Green Training -> OCBE & 0.694 & 9.748 & 0.000 & $\begin{array}{l}\text { Significantly } \\
\text { Positive Influence }\end{array}$ \\
\hline $\begin{array}{l}\text { - Green Recruitment } \rightarrow \text { Employee } \\
\text { Performance }\end{array}$ & 0.169 & 2.220 & 0.027 & $\begin{array}{l}\text { Significantly } \\
\text { Positive Influence }\end{array}$ \\
\hline $\begin{array}{l}\text { - Green Training -> Employee } \\
\text { Performance }\end{array}$ & 0.390 & 3.291 & 0.001 & $\begin{array}{l}\text { Significantly } \\
\text { Positive Influence }\end{array}$ \\
\hline - OCBE -> Employee Performance & 0.418 & 3.558 & 0.000 & $\begin{array}{l}\text { Significantly } \\
\text { Positive Influence }\end{array}$ \\
\hline \multicolumn{5}{|l|}{ Indirect Effects } \\
\hline $\begin{array}{l}\text { - Green Recruitment }>>\text { OCBE }>>\text { Employee } \\
\text { Performance }\end{array}$ & 0.110 & 2.483 & 0.013 & $\begin{array}{l}\text { Significantly } \\
\text { Positive Influence }\end{array}$ \\
\hline $\begin{array}{l}\text { - Green Training -> OCBE -> Employee } \\
\text { Performance }\end{array}$ & 0.290 & 3.274 & 0.001 & $\begin{array}{l}\text { Significantly } \\
\text { Positive Influence }\end{array}$ \\
\hline
\end{tabular}

Source: Results of analysis using SmartPLS 3.2.8

Hypothesis Testing in this study are as follows:

\section{1) Green Recruitment has positive significant effect on OCBE}

From observations at PT TRU, employees have the drive and awareness to maintain a higher work environment and take concrete actions in environmental management such as making reports via email thereby reducing paper usage.Therefore Hypothesis ${ }_{1}$ in this study which states that "Green Recruitment $\left(\mathrm{X}_{1}\right)$ has a significant effect on OCBE $\left(\mathrm{Y}_{1}\right)$ " is accepted.

\section{2) Green Training has positive significant effect on OCBE}

Theprocess Green Training carried out at PT TRU has been running optimally and structured. The training provided by the company istraining e-learning. E-learning is internet based learning where employees participate in multimedia simulations or other interactive modules. Therefore Hypothesis $\mathrm{H}_{2}$ in this study which states that "Green Training $\left(\mathrm{X}_{2}\right)$ has a significant effect on OCBE $\left(\mathrm{Y}_{1}\right) "$ is accepted. 


\section{3) OCBE has positive significant effect on Employee Performance}

In this organizationare also applied change agents in each department where designated employees are tasked with motivating other employees to care for the environment. Thus, good habits of employees with environmental awareness will improve the quality of employee performance. Therefore hypothesis $\mathrm{H}_{3}$ in this study which states that "OCBE $\left(\mathrm{Y}_{1}\right)$ has a significant effect on Employee Performance $\left(\mathrm{Y}_{2}\right)$ " is accepted.

\section{4) Green Recruitment has positive significant effect on Employee Performance}

The knowledge and competencies of employees is needed by the company to know the employees extent can work optimally and contribute in accordance with what the company wants. If employees already work in accordance with competencies, employees will like their work and will improve the work of higher quality that can improve employee performance. Therefore hypothesis $\mathrm{H}_{4}$ in this study which states that Green Recruitment $\left(\mathrm{X}_{1}\right)$ a significant effect on employee performance (Y2)" is accepted.

\section{5) Green Training has positive significant effect on Employee Performance}

With the trained employees presence, it will produce good productivity. The training model provided at PT TRU is in the e-learning website based form that facilitates participant access as well as the development of sustainable programs in the future. Website based elearning media are considered effective enough to deliver online training and tests resulting in an increase in employee performance.Therefore Hypothesis 5 in this study which states that "Green Training $\left(\mathrm{Y}_{1}\right)$ has a significant effect on Employee Performance $\left(\mathrm{Y}_{2}\right)$ is accepted.

6) Green Recruitment has positive significant effect on Employee Performance through the OCBE variable

Based on the observation that Green Recruitment has been carried out by PT. TRU has used an online process that will affect the Organization Citizenship Behavior for Environment in which employees will have voluntary behavior towards the environment so that it can improve the employees performance at PT.TRU.Therefore Hypothesis $\mathrm{H}_{6}$ in this study which states that "Green Recruitment $\left(\mathrm{X}_{1}\right)$ a significant effect on employee performance $\left(\mathrm{Y}_{2}\right)$ through OCBE variable $\left(\mathrm{Y}_{1}\right)^{\prime}$ is accepted.

7) Green Training has positive significant effect on Employee Performance through the OCBE variable

Based on the observation that Green Training that has been carried out by PT. TRU has used the e-learning process which affect the Organization Citizenship Behavior for Environment where employees have voluntary behavior towards the environment so that it can improve the employees performance at PT.TRU. Therefore hypothesis $\mathrm{H}_{7}$ in this study which states that"GreenTraining $\left(\mathrm{X}_{2}\right)$ significantly affects employee performance $\left(\mathrm{Y}_{2}\right)$ through OCBE (Y1)" is accepted.

\section{Mediation Effect Test}




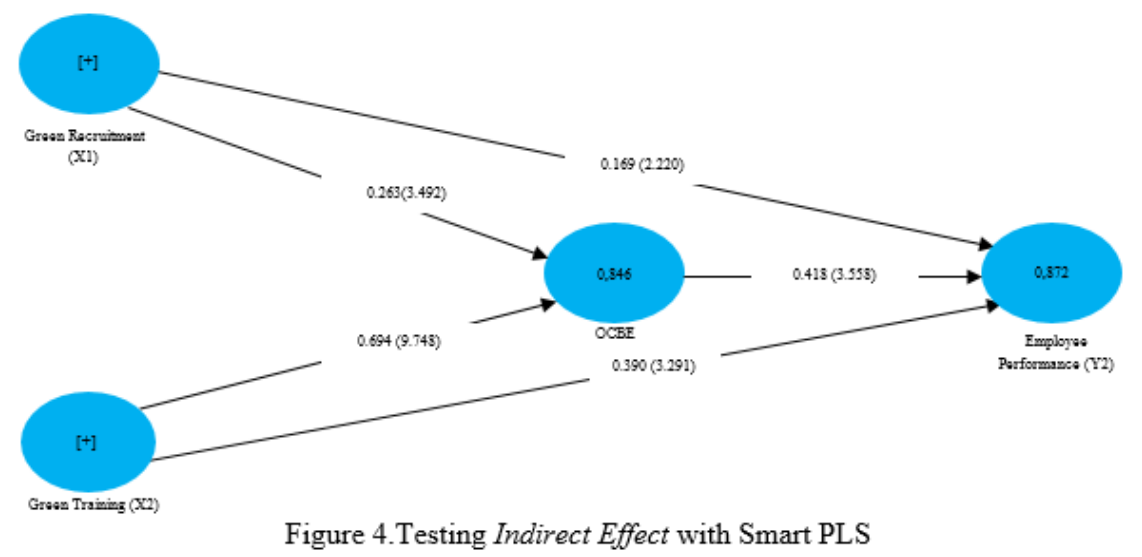

If the indirect coefficient value is greater than the direct coefficient value ${ }^{2,}$ it mediates, so that $\mathrm{H}_{6}$ : Green Recruitment has a positive and significant effect on Employee Performance through OCBE (accepted) and $\mathrm{H}_{7}$ :Green Training has a positive and significant effect on Employee Performance through OCBE (accepted)

\section{CONCLUSION AND SUGESTION}

\section{Conclusion}

Based on the discussion regarding the Effect of Green Recruitment, and Green Training, on OCBE, and Employee Performance at PT TRU the following conclusions are:

1) Green recruitment, green training, and Organization Citizenship for Behavior (OCBE) positive and significant effect on employee performance.

2) Green recruitment and green training have a positive and significant effect on employee performance through the Organization Citizenship for Behavior (OCBE).

\section{Suggestions}

1) The recruitment process can be done by online facilitate of HR management in recruiting employees who have knowledge of managing the environment. Employees who have knowledge about the environment will want to actively participate in activities organized by the company to manage the environment.

2) Good HR management on employee recruitment process creates a job description for candidates who have knowledge in managing the environment to obtain a quality workforce that suits what organization needed.

3) HR Management conducts capacity building in training form on environmental management which can improve employees knowledge and skills in managing the environment.

4) HR management is increasing training on environmental management and evaluating the training that has been done. And there is motivation from management to attend training that has a positive impact on the organization. Training can be done with e-learning methods where employees participate in multimedia simulations or other interactive modules. Training can improve the quality of employee work. 
5) HR management should internalize through a coaching program to each unit regarding the importance of managing the environment. This activity can make employees become aware of the environment and employee collaboration will be created to protect the environment. HR management can also hold various activities where all employees are involved in environmental management activities. Activities undertaken can be in the form of CSR to the environment that can enhance the company's image.

\section{REFERENCES}

Alnajdwi, Sakher, Hamzah Elrehail, Okechukwu Lawrence Emeagwali, Gangxuan Liu. (2017). The Interplay among Green Human Resources Practices, Organization Citizenship Behvior for Environment and Sustainable Corporate Performance: Evidence From Jordan. Vol. 5. No. 3. pp:171-184.

Astuti, Mudji dan Hana Catur Wahyuni. (2018). "Strategi Implementasi Green Human Resource Management pada Usaha Mikro, Kecil dan Menengah (UMKM)". Volume 12, No 2, Agustus 2018.

Bin, Bilal Saeed, Bilal Afsar, Shakir Hafeez, Imran Khan, Muhammad Tahir, Muhammad Asim Afridi. (2018). "Promoting Employee's Proenvironmental Behaviour Through Green Human Resource Management Practices".

Boiral, O. Talbot, D. \& Paillé, P. (2015). "Leading by example: A model of organizational citizenship behavior for the environment. Business Strategy and the Environment". Vol 24, September 2015. pp: 532-550.

Ghozali, Imam. (2014) . Structural Equation Modelling Metode Alternatif dengan Partial Least Square (PLS). Edisi 4. Badan Penerbit Universitas Diponegoro, Semarang.

Hossen ,Md Miraj. (2018). "Managing Human Resource Through Green Policy : Ways Out and its Implication".

Jabbour, Charbel Jose Chiappetta. (2015). "Environmental training and environmental management maturity of Brazilian companies with ISO14001: Empirical evidence". Vol 96, 1 Juni 2015. pp: 331-338.

Jia, Jianfeng; Huanxin Liu, Tachia Chin, dan Dongqing Hu. (2018). "The Continuous Mediating Effects of GHRM on Employees' Green Passion via Transformational Leadership and Green Creativity". Vol. 10(9), September. pp: 1-18.

Kinicki, Angelo dan Fugate. (2013). Organizational Behaviour:Key Concepts, Skills and Best Practices. 5th Edition.New York: McGraw-Hill Education.

Kumarasinghe K.K.A.H dan Pallewaththa P.W.K. (2018). "The effects of green training and development practices on employee performance". Vol. 17, No. 2, December 2018. pp: 49-58.

Lenny \&Ahmad.(2018). The Impact of Human Resources Practices Affecting Organization Citizenship Behaviours with Mediating Job Satisfaction in University. The 3th Annual International Seminar on Transformative Education and Educational LeadershipUnimed.

Moeheriono. (2012). Pengukuran Kinerja Berbasis Kompetensi. Jakarta: Raja Grafindo Indonesia. 
Oaya, Zirra Clifford Tizhe; Ogbu James Ogbu, dan Ojo Grace Remilekun. (2017). "Impact of Recruitment and Selection Strategy on Employees' Performance: A Study of Three Selected Manufacturing Companies in Nigeria".

Pham, Nhat Tan; Quyen Phu Thi Phan dan Zuzana Tuckova. Nga VO. (2018). "Enhancing the organizational citizenship behavior for the environment: the roles of green training and organizational culture; Sciendo". Vol. 13(4), pp: 1174-1189.

Posarajan, Aranganathan. (2018). "Green Recruitment: a new-fangled approach to attract and retain talent”. Vol. 8, No 2, Apr 2018, pp: 69-76.

Ragas, Sheena Fatima Paro; Flora Mae Angub Tantay, Lorraine Joyce Co Chua dan Carolyn Marie Concha Sunio. (2017). "Green lifestyle moderates GHRM's impact to job performance". Vol 66, No. 7. 2017. pp: 838.

Ramasamy, Adimuthu; Ishmael Inore, dan Richard Sauna. (2017). "A Study on Implications of Implementing Green HRM in the Corporate Bodies with Special Reference to Developing Nations". Vol. 12, No. 9, 2017.

Wulansari, Nury Ariani; Rini Setyo Witiastuti, dan Siti Ridloah. (2018). "Employee Performance Measurement Development Based on Green HRM Indicators". 